\title{
Common urological problems in children: prepuce, phimosis, and buried penis
}

\author{
Ivy HY Chan, Kenneth KY Wong *
}

This article was published on 6 May 2016 at www.hkmj.org.

\section{A B S T R A C T}

Parents often bring their children to the family doctor because of urological problems. Many general practitioners have received little training in this specialty. In this review, we aimed to provide a concise and informative review of common urological problems in children. This review will focus on the prepuce.
Hong Kong Med J 2016;22:263-9

DOI: 10.12809/hkmj154645

IHY Chan, FRCSEd(Paed), FHKAM (Surgery)

KKY Wong *, PhD, FHKAM (Surgery)

Division of Paediatric Surgery, Department of Surgery, The University of Hong Kong, Queen Mary Hospital, Hong Kong

* Corresponding author: kkywong@hku.hk

\section{Introduction}

Young boys are often brought by parents to see a medical practitioner for 'phimosis', and circumcision is one of the most commonly performed operations. Yet this topic is often not taught routinely in medical school. Buried penis is another less well-defined condition. In this review article, we will describe these conditions in a more systematic manner and present the current available knowledge about the conditions and management options.

\section{Normal development of the prepuce and phimosis}

Phimosis generally refers to a condition where the prepuce cannot be withdrawn to expose the glans. True phimosis, however, should be defined as a pathological condition in which the prepuce is scarred, non-retractile, and with a narrow preputial ring. This is secondary to balanitis xerotica obliterans (BXO). To avoid confusion of the terms, 'physiological phimosis' and 'pathological phimosis' should be used.

\section{Physiological phimosis}

Physiological phimosis is a natural condition in which the prepuce cannot be retracted and there is natural adhesion between the glans and the prepuce (Fig 1). Almost all normal male babies are born with a non-retractable foreskin. Indeed, Gairdner ${ }^{1}$ noticed only 4\% of newborns in England and Wales had retractable foreskin. The foreskin becomes retractable as the child grows. The adhesion between the prepuce and glans will also separate gradually as a spontaneous biological process. ${ }^{2-4}$ By the age of 3 years, $90 \%$ of prepuces are retractable. ${ }^{1} \varnothing$ ster $^{2}$ examined preputial development in 173 Danish boys aged 6 to 17 years annually for 7 years and determined that the foreskin was non-retractable in $8 \%$ of young boys but in only $1 \%$ at 17 years of age. Similar findings were noted in Chinese boys by Ko et $\mathrm{al}^{5}$ and Hsieh et al, ${ }^{6}$ who reported $84.1 \%{ }^{5}$ and $58.1 \%^{6}$ of boys with a completely retractable prepuce by the age of 13 years. Both the retractability and the shape of the prepuce lie within a spectrum that can sometimes be difficult to describe and there is no agreed classification system. Different papers have used their own classifications for the purpose of study. One example was the study by Kayaba et $\mathrm{al}^{3}$ in which retractability was graded according to how much of the glans was visible after prepuce retraction.

\section{Pathological phimosis/balanitis xerotica obliterans}

Balanitis xerotica obliterans is a chronic and progressive inflammatory condition that affects the prepuce, glans, and sometimes the urethra (Fig 2). It was first described in 1928 by Stühmer. ${ }^{7}$ There are three components of this condition: 'balanitis', meaning chronic inflammation of the glans penis; 'xerotica', an abnormally dry appearance of the lesion;

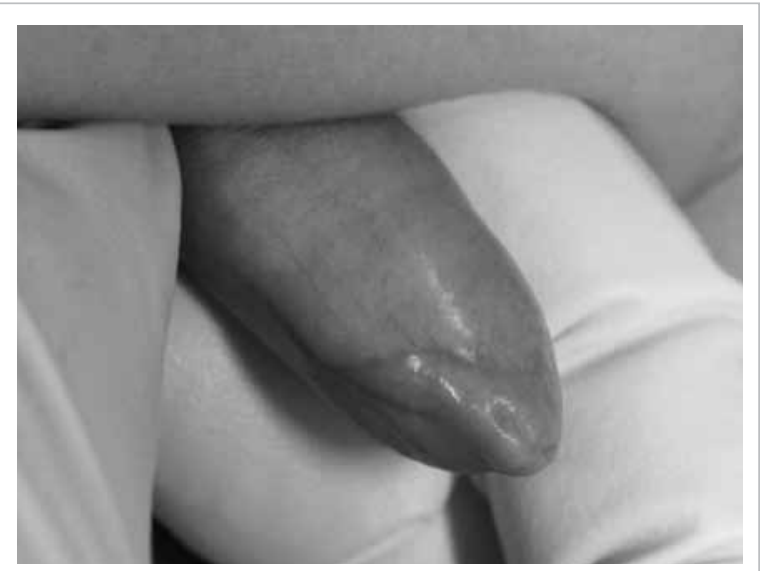

FIG I. Physiological phimosis 


\section{常見的小兒泌尿系統問題：包皮過長、包莖和 隱匿性陰莖 \\ 陳巧兒、黃格元 \\ 泌尿系統問題是父母帶孩子就醫的常見原因。然而對於許多家庭醫生 來説, 有關泌尿系統問題的醫療培訓並不太深入。我們希望針對常見 的小兒泌尿系統問題作一扼要闡述。本文將集中討論有關小兒包皮的 病症。}

'foreskin problems'. Pain, redness, itchiness, long prepuce, ballooning during urination, difficulty in retracting the prepuce, and penis being too short are the common complaints. Before answering all the questions, we should be able to differentiate the normal and abnormal.

\section{Pain, pruritus, smegma}

Most parents may think that the presence of pain or pruritus indicates infection of the prepuce, and yet poor prepuce hygiene is a more common problem. Smegma is another common complaint from parents, usually described as a 'mass', or 'white pearl'. Smegma can be identified by gently retracting the prepuce (Fig 3). It is harmless and is a combination of secretions and desquamated skin.

\section{Difficulty in retracting the prepuce and long prepuce}

Difficulty in retracting the prepuce and long prepuce is a feature of physiological phimosis. This is normal in most boys and requires no attention apart from daily routine prepuce hygiene. The role of the physician is to differentiate normal and abnormal prepuce, then guide proper management.

\section{Ballooning}

Ballooning is a feature of a tight prepuce. Because of the tight preputial opening, there is dilatation of the preputial sac during voiding. This causes a lot of parental anxiety about possible urinary outflow obstruction. Babu et $\mathrm{al}^{10}$ performed uroflow studies in boys with and without ballooning of the foreskin and determined that there was significant difference.

and 'obliterans', for the association of occasional endarteritis.

The aetiology and the true incidence is unknown. An incidence of $0.6 \%$ has been reported for boys affected by their 15 th birthday. ${ }^{8}$ It is suspected clinically when there is a ring of hardened tissue with a whitish colour at the tip of the foreskin. There are also other clinical features such as white patches over the glans, perimeatal sclerotic changes, or meatal stenosis. It can cause urethral stricture and retention of urine.

Medical students are not taught about the condition and it is generally not diagnosed at the primary care level. Gargollo et $\mathrm{al}^{9}$ reviewed 41 patients with the pathologically confirmed diagnosis of BXO at their centre and confirmed that no patient had the diagnosis at referral. Pathology of the excised prepuce showed lymphocytic infiltration in the ripper dermis, hyalinosis and homogenisation of collagen, basal cell vacuolation, atrophy of the stratum malpighii, and hyperkeratosis.

\section{Potential clinical problems}

Parents often seek medical advice about their son's

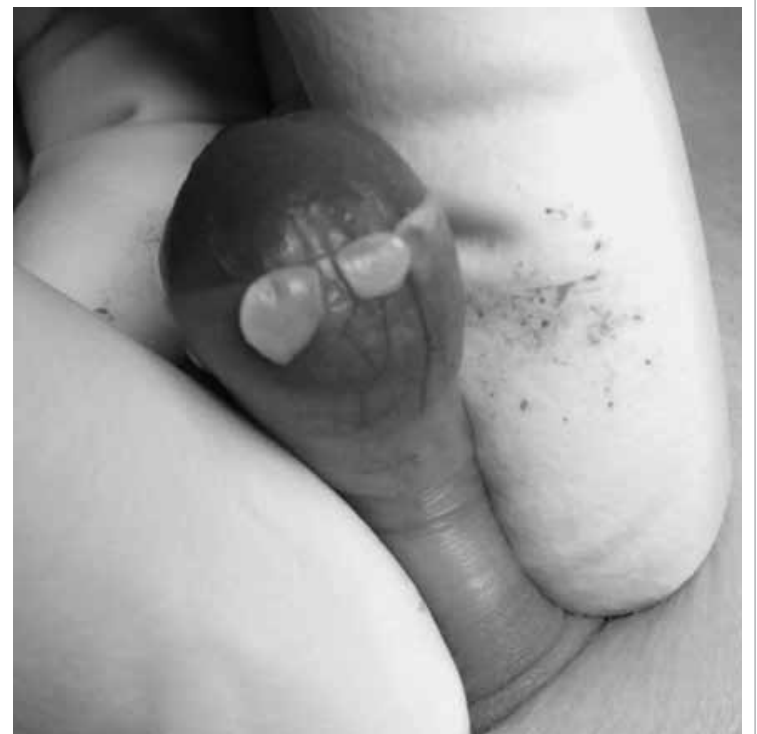

FIG 3. Smegma seen after retracting the prepuce during circumcision 


\section{Balanoposthitis}

This refers to inflammation of the glans (balanitis) and the foreskin (posthitis) [Fig 4]. Patients present with a swollen prepuce with or without discharge from the preputial opening. It is a relatively common condition, with a reported incidence of $6 \%$ in uncircumcised boys. ${ }^{11}$ In the absence of fever, underlying urinary tract infection (UTI) is unlikely. Simple bathing and rinsing with normal saline or chlorhexidine gluconate solution after urination is sufficient treatment for afebrile patients. Topical antibiotic cream is commonly prescribed for local infection. Serious conditions and presence of fever may warrant further investigations, oral antibiotics, or even hospital admission.

\section{Clinical management of phimosis}

\section{Prepuce hygiene and retraction}

After diagnosing physiological phimosis, parents should be taught how to keep the prepuce clean. Only a small proportion of parents know what is required. ${ }^{12}$ Gentle daily retraction of the prepuce and rinsing of the prepuce with warm water can maintain good hygiene and prevent infection. Parents should also be taught to avoid forcible retraction of the prepuce. ${ }^{13-15}$ Simple stretching of the prepuce alone has been shown to be effective in achieving complete resolution of physiological phimosis. ${ }^{16}$ After 3 months of prepuce stretching, $76 \%$ of patients reported resolution of phimosis. ${ }^{16}$

\section{Topical steroids}

Topical steroids have been prescribed in the treatment of phimosis. Their anti-inflammatory, immunosuppressive, and skin-thinning properties

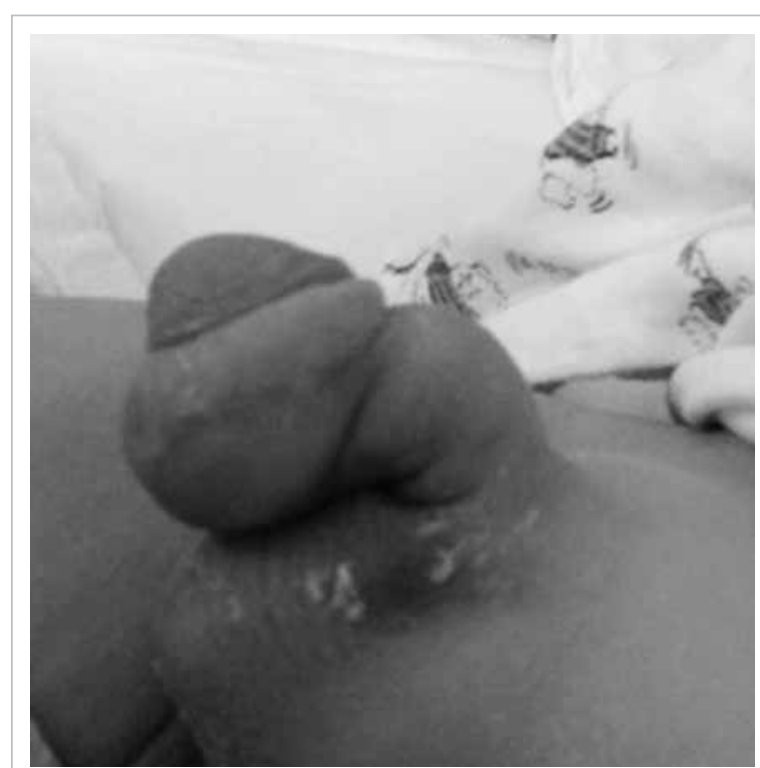

FIG 4. Balanoposthitis are believed to be the mechanism for resolution of phimosis. ${ }^{17}$ Their use in physiological phimosis was first described by Kikiros et al. ${ }^{18}$ Subsequent studies showed the response rate for resolution of phimosis to be $68.2 \%$ to $95 \%{ }^{16,19-22}$ Moreno et al ${ }^{23}$ subsequently performed a meta-analysis and reviewed 12 randomised controlled trials on the use of different topical steroid formulations, and again confirmed the significant benefit of corticosteroids in the complete or partial clinical resolution of phimosis (risk ratio $=2.45 ;$ 95\% confidence interval, 1.84-3.26).

Parents often ask about the potential complications of topical steroid use. Golubovic et $\mathrm{al}^{24}$ and Pileggi et $\mathrm{al}^{25}$ addressed this issue by measuring serum cortisol levels and salivary cortisol levels, respectively. Neither could demonstrate a significant change in cortisol level after application of topical steroids. Topical steroid therapy is thus a safe and effective alternative to circumcision.

\section{Circumcision}

Circumcision is a procedure in which part of the foreskin is removed and results in a non-covered glans. It is a procedure that has been described for many years and is performed almost universally in Jewish and Muslim boys. The rate of newborn circumcision is high in the US $(>50 \%),{ }^{26,27}$ but routine circumcision is not a tradition in the Chinese population. Leung et $\mathrm{al}^{28}$ showed the circumcision rate in 6- to 12-year-old boys in Hong Kong to be $10.7 \%$.

\section{Benefits versus risks of circumcision}

There is evidence that circumcision can reduce the risk of UTI, penile cancer, human immunodeficiency virus (HIV), and sexually transmitted disease (STD).

\section{Urinary tract infection}

Childhood UTI is associated with renal scarring. The symptoms and signs of UTI are often non-specific in young children who may present with fever alone. The overall prevalence of UTI in children with fever $(<19$ years old) was reported to be $7.8 \%$ in a meta-analysis published in 2008. ${ }^{29}$ The pooled prevalence of febrile UTI in male infants from 0 to 24 months of age was 8.0\% (confidence interval, 5.5-10.4\%). Circumcised boys had a lower risk of developing UTI-20.1\% in uncircumcised versus $2.4 \%$ in circumcised infants of less than 3 months of age with fever. ${ }^{29}$

Another systematic review in 2005 showed a decreased risk of UTI in circumcised boys. ${ }^{30}$ The authors calculated the number-needed-to-treat was 111 in normal boys, but the number-needed-to-treat for recurrent UTI and high-grade vesicoureteric reflux was 11 and 4, respectively. It was evident that the benefits of circumcision were higher for boys at risk of UTI. 


\section{Sexually transmitted infection and human immunodeficiency virus}

Three randomised controlled trials concluded that adult circumcision had a protective effect against acquisition of HIV. ${ }^{31-33}$ Although the full mechanism of protection was not fully understood, it was shown that the inner foreskin harbours epithelial CD4+ CCR5 + cells and has features of an inflamed epidermal barrier. These changes may support a subclinical inflammatory state in uncircumcised men, with availability of target cells for HIV infection, and potentially account for the benefits of circumcision in STD prevention. ${ }^{34}$ All the trials were performed in Africa, with a much higher prevalence of HIV. Education about use of condoms and safe sex practice was relatively primitive compared with Hong Kong. Readers should therefore interpret these results with caution when discussing the benefits of circumcision on HIV prevention with our patients.

A meta-analysis published in 2006 by Weiss et $\mathrm{al}^{35}$ showed that circumcised males were at a lower risk of syphilis, and there was a lower association with herpes simplex virus (HSV) type 2. Other cohorts also showed similar findings, with circumcised males having a decreased risk of syphilis, gonorrhoea, and human papillomavirus (HPV). ${ }^{36-39}$ On the contrary, another systematic review by Van Howe ${ }^{40}$ showed that most STDs are not impacted significantly by circumcision status. They included chlamydia, gonorrhoea, HSV, and HPV. Despite the positive findings in some studies, it should be remembered that the use of a condom and safe sex are the most important deterrents. The protective effect of circumcision might give a false sense of security and should not be advocated over other preventive measures.

\section{Risks and complications of circumcision}

Circumcision is one of the most commonly performed operations in the world and involves excision of a ring of preputial tissue. In general, the procedure may involve the use of a special device (eg Plastibell, Gomco clamp, Mogen clamp, Shang ring) or may apply the 'free hand excision method'. Depending on the method, suturing may or may not be involved. Every procedure is associated with risks and complications. The rate is different depending on the operator (ritual circumciser or surgeon) and the setting (home, clinic, or hospital).

There has been inadequate comparison of the complication rates of 'device method' surgery and the 'free hand excision method' so it is difficult for the authors to recommend a single best method for surgical circumcision. The overall complication rate of circumcision varies from $0.5 \%{ }^{41}$ to $8 \%{ }^{42}$ As the indication for circumcision in some patients is not medical (eg religious or ritual circumcision), the risks should be carefully explained to the patient before the procedure.

Early complications include bleeding, wound infection, and UTI. Bleeding is one of the most common postoperative complications that, in extreme cases, may lead to shock. ${ }^{43}$ Meticulous technique during the procedure is thus important. If bleeding is encountered postoperatively, it can usually be controlled by local compression or bedside plication.

In a UK study, the infection rate after circumcision has been reported to be around $0.3 \% .^{44}$ It is usually minor and can be treated by simple irrigation with antiseptic solution. Systemic antibiotics are rarely needed. A systematic review of the prevalence and complications of circumcision was performed in eastern and southern Africa. ${ }^{45}$ The infection rate was very high and two thirds of patients presented with systemic infection requiring antibiotics. The authors believe the quality of local wound care is very important in minimising the infection rate. Urinary retention is uncommon after circumcision but can occur in up to $3.6 \%$ of cases. It is likely to be pain-related or due to improper placement of a circumcision device, eg Plastibell. ${ }^{46}$

Wound dehiscence may occur and can be managed with wound care and dressing. Very rarely, excessive prepuce loss as a result of excessive skin excision may be seen. This potentially disastrous complication has been reported to be treated with a full-thickness skin graft. ${ }^{47}$

Late complications are not uncommon, reported by one study to be present in $4.7 \%$ of newborn circumcisions. ${ }^{48}$ Redundant residual skin and recurrent penile adhesion are the two most common late complications that may necessitate revision circumcision. Meatal stenosis is another late but uncommon complication after circumcision and requires surgery. The cause is not known but it is more common in patients with BXO. ${ }^{49,50}$

There are some other less-common but severe complications, including urethrocutaneous fistula, glans amputation, and iatrogenic buried penis..$^{51,52}$ These have long-term physiological and psychological consequences for both the patient and family. Surgical technique and the surgeon's awareness of limitations of each method of circumcision is important. Parents should be fully informed before they make a decision about circumcision, especially where the patient is physically weak or where there is no medical indication for the procedure.

\section{Current guidelines on circumcision}

Various international colleges have produced guidelines on circumcision. These include the British Association of Paediatric Surgeons, ${ }^{53}$ the Royal Australasian College of Physicians, ${ }^{54}$ and the American Academy of Pediatrics. ${ }^{55,56}$

Having taken all these into account, the overall 
view of our unit is as follows:

(1) Although there is some scientific evidence for the benefits of circumcision, the routine use on all males is not justified. Parents should be fully informed of all the potential benefits and risks of the procedure.

(2) Our current medical indications for circumcision are:

(a) penile malignancy (although this is extremely rare in children) or traumatic foreskin injury where it cannot be salvaged; and

(b) BXO, severe recurrent attacks of balanoposthitis, and/or recurrent febrile UTIs.

(3) Non-therapeutic 'ritual' circumcision may be offered.

\section{Buried penis}

Buried penis is a condition where the penis is 'trapped' or 'concealed' under the suprapubic area. There is an apparent absence or partial absence of the penis. Figure 5 shows partial buried penis in an 8-year-old boy. The condition was described as 'complete' or 'partial' by Crawford ${ }^{57}$ in 1977 . In the partial type, the proximal half of the penile shaft is buried in the subcutaneous tissue. For the complete type, the phallus is completely invisible and the glans is covered only by prepuce. Maizels et $\mathrm{al}^{58}$ further elaborated in 1986, offering new classifications as 'buried penis' (patients with redundant suprapubic fat and/or lack of penile skin anchoring to deep fascia), 'webbed penis' (scrotal skin webs the penoscrotal angle to obscure the penis), 'trapped penis' (the shaft of the penis is entrapped in the scarred, prepubic skin following trauma/overzealous circumcision), 'micro-penis' (a normally formed penis that is less than two standard deviations below the mean size in the stretched length), and 'diminutive penis' (a penis that is small and/or malformed as a consequence of epispadias/exstrophy, severe hypospadias, disorder of sexual differentiation, or chromosomal anomalies). O'Brien et $\mathrm{al}^{59}$ described another condition called 'congenital megaprepuce' in 1994 that includes a phimotic ring and large preputial sac. Despite these studies, buried penis is still not a well-defined or well-classified entity. It can be congenital or iatrogenic after overzealous circumcision. Clinicians are reminded to examine the penis carefully and the exact penile length should be a properly performed 'stretched penile length'. When there is uncertainty about the exact diagnosis, early specialist advice is advocated.

\section{Clinical problems}

For congenital problems, anxious parents usually seek medical advice because they feel that their child's penis is too short. Other problems include

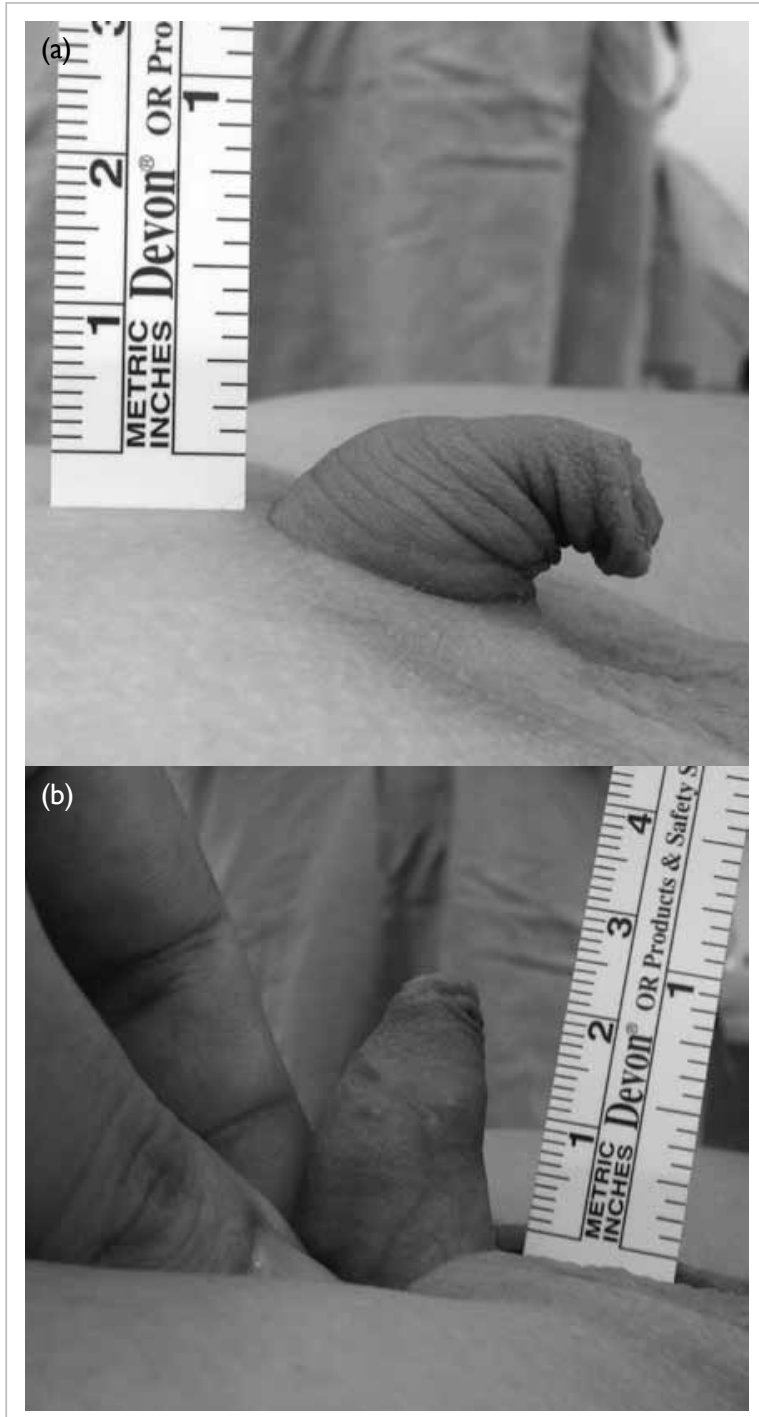

FIG 5. (a) A patient with buried penis and apparent short penis, and (b) the same patient after stretching the prepuce. The actual length of penis is concealed by the suprapubic fat in this patient

local infection, urinary retention, inability to void standing, chronic urinary dripping, and undirected voiding. For older children, there may be pain during erection or disturbed vaginal penetration. ${ }^{60-62}$

\section{Management}

Anatomically, buried penis is usually due to insufficient outer prepuce and lack of attachment between the penile Buck's fascia and the pubis. ${ }^{63}$ Numerous corrective surgical techniques have been described. The underlying principle is the degloving of the penis, anchoring of Buck's fascia to the pubis, and preputioplasty (pedicled preputial flap, Z-plasty of the prepuce, lipectomy, and skin graft) [Fig 6]. ${ }^{64,65}$

A study on the comparison of quality of life before and after surgery showed significant 


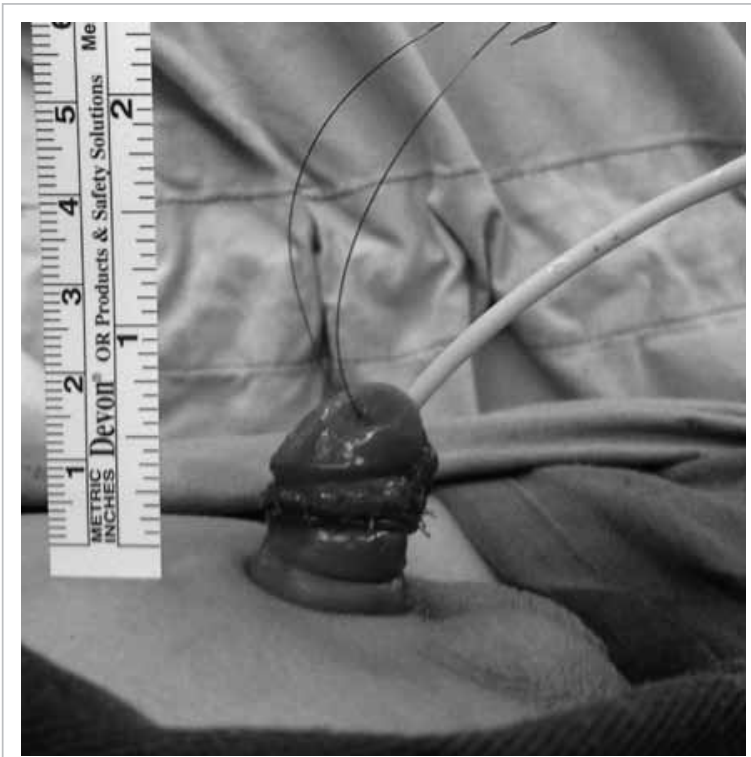

FIG 6. Appearance after preputioplasty for buried penis

improvement in sexual pleasure, urination difficulties, and genital hygiene. ${ }^{66}$ King et $\mathrm{al}^{61}$ also reported that all patients were happy with the aesthetic results.

\section{Conclusions}

It is essential to recognise the features of physiological versus pathological phimosis. Physiological phimosis (tightness of prepuce), preputial adhesion, and smegma are common and normal in young boys, and do not require surgical intervention. There are potential benefits and complications of circumcision that should be thoroughly appreciated by physicians before discussion with parents or patient. Medical indications for circumcision include penile malignancy, traumatic foreskin injury, recurrent attacks of severe balanoposthitis, and recurrent febrile UTIs with abnormal urinary tract. Very few international societies support routine circumcision despite the potential medical benefits incurred. Buried penis is a condition that may warrant surgery.

\section{References}

1. Gairdner D. The fate of the foreskin, a study of circumcision. Br Med J 1949;2:1433-7.

2. Øster J. Further fate of the foreskin. Incidence of preputial adhesions, phimosis, and smegma among Danish schoolboys. Arch Dis Child 1968;43:200-3.

3. Kayaba H, Tamura H, Kitajima S, Fujiwara Y, Kato T, Kato T. Analysis of shape and retractability of the prepuce in 603 Japanese boys. J Urol 1996;156:1813-5.

4. Rickwood AM. Medical indications for circumcision. BJU Int 1999;83 Suppl 1:45-51.

5. Ko MC, Liu CK, Lee WK, Jeng HS, Chiang HS, Li CY. Agespecific prevalence rates of phimosis and circumcision in Taiwanese boys. J Formos Med Assoc 2007;106:302-7.
6. Hsieh TF, Chang $\mathrm{CH}$, Chang SS. Foreskin development before adolescence in 2149 schoolboys. Int J Urol 2006;13:968-70.

7. Stühmer A. Balanitis xerotica obliterans (post operationem) und ihre Beziehungenzur 'Kraurosis glandi et praeputii penis' [in German]. Arch Dermatol Syph (Berlin) 1928;156:613.

8. Shankar KR, Rickwood AM. The incidence of phimosis in boys. BJU Int 1999;84:101-2.

9. Gargollo PC, Kozakewich HP, Bauer SB, et al. Balanitis xerotica obliterans in boys. J Urol 2005;174:1409-12.

10. Babu R, Harrison SK, Hutton KA. Ballooning of the foreskin and physiological phimosis: is there any objective evidence of obstructed voiding? BJU Int 2004;94:384-7.

11. Herzog LW, Alvarez SR. The frequency of foreskin problems in uncircumcised children. Am J Dis Child 1986;140:254-6.

12. Osborn LM, Metcalf TJ, Mariani EM. Hygienic care in uncircumcised infants. Pediatrics 1981;67:365-7.

13. Camille CJ, Kuo RL, Wiener JS. Caring for the uncircumcised penis: what parents (and you) need to know. Contemp Pediatr 2002;11:61.

14. Simpson ET, Barraclough P. The management of the paediatric foreskin. Aust Fam Physician 1998;27:381-3.

15. Rickwood AM, Hemalatha V, Batcup G, Spitz L. Phimosis in boys. Br J Urol 1980;52:147-50.

16. Zampieri N, Corroppolo M, Camoglio FS, Giacomello L, Ottolenghi A. Phimosis: stretching methods with or without application of topical steroids? J Pediatr 2005;147:705-6.

17. Kragballe K. Topical corticosteroids: mechanisms of action. Acta Derm Venereol Suppl (Stockh) 1989;151:7-10; discussion 47-52.

18. Kikiros CS, Beasley SW, Woodward AA. The response of phimosis to local steroid application. Pediatr Surg Int 1993;8:329-32.

19. Lee $\mathrm{CH}$, Lee SD. Effect of topical steroid $(0.05 \%$ clobetasol propionate) treatment in children with severe phimosis. Korean J Urol 2013;54:624-30.

20. Chu CC, Chen KC, Diau GY. Topical steroid treatment of phimosis in boys. J Urol 1999;162:861-3.

21. Orsola A, Caffaratti J, Garat JM. Conservative treatment of phimosis in children using a topical steroid. Urology 2000;56:307-10.

22. Ghysel C, Vander Eeckt K, Bogaert GA. Long-term efficiency of skin stretching and a topical corticoid cream application for unretractable foreskin and phimosis in prepubertal boys. Urol Int 2009;82:81-8.

23. Moreno G, Corbalán J, Peñaloza B, Pantoja T. Topical corticosteroids for treating phimosis in boys. Cochrane Database Syst Rev 2014;(9):CD008973.

24. Golubovic Z, Milanovic D, Vukadinovic V, Rakic I, Perovic $\mathrm{S}$. The conservative treatment of phimosis in boys. Br J Urol 1996;78:786-8.

25. Pileggi FO, Martinelli CE Jr, Tazima MF, Daneluzzi JC, Vicente YA. Is suppression of hypothalamic-pituitaryadrenal axis significant during clinical treatment of phimosis? J Urol 2010;183:2327-31.

26. Centers for Disease Control and Prevention (CDC). Trends in in-hospital newborn male circumcision-United States, 1999-2010. MMWR Morb Mortal Wkly Rep 2011;60:11678.

27. Warner L, Cox S, Kuklina E, et al. Updated trends in the incidence of circumcision among male newborn delivery hospitalizations in the United States, 2000-2008. 
Proceedings of the National HIV Prevention Conference; 2011 Aug 26; Atlanta, Georgia, US.

28. Leung MW, Tang PM, Chao NS, Liu KK. Hong Kong Chinese parents' attitudes towards circumcision. Hong Kong Med J 2012;18:496-501.

29. Shaikh N, Morone NE, Bost JE, Farrell MH. Prevalence of urinary tract infection in childhood: a meta-analysis. Pediatr Infect Dis J 2008;27:302-8.

30. Singh-Grewal D, Macdessi J, Craig J. Circumcision for the prevention of urinary tract infection in boys: a systematic review of randomised trials and observational studies. Arch Dis Child 2005;90:853-8.

31. Gray RH, Kigozi G, Serwadda D, et al. Male circumcision for HIV prevention in men in Rakai, Uganda: a randomised trial. Lancet 2007;369:657-66.

32. Bailey RC, Moses S, Parker CB, et al. Male circumcision for HIV prevention in young men in Kisumu, Kenya: a randomised controlled trial. Lancet 2007;369:643-56.

33. Auvert B, Taljaard D, Lagarde E, Sobngwi-Tambekou J, Sitta R, Puren A. Randomized, controlled intervention trial of male circumcision for reduction of HIV infection risk: the ANRS 1265 Trial. PLoS Med 2005;2:e298.

34. Lemos MP, Lama JR, Karuna ST, et al. The inner foreskin of healthy males at risk of HIV infection harbors epithelial CD4+ CCR5+ cells and has features of an inflamed epidermal barrier. PLoS One 2014;9:e108954.

35. Weiss HA, Thomas SL, Munabi SK, Hayes RJ. Male circumcision and risk of syphilis, chancroid, and genital herpes: a systematic review and meta-analysis. Sex Transm Infect 2006;82:101-9; discussion 110.

36. Diseker RA 3rd, Peterman TA, Kamb ML, et al. Circumcision and STD in the United States: cross sectional and cohort analyses. Sex Transm Infect 2000;76:474-9.

37. Albero G, Castellsagué X, Giuliano AR, Bosch FX. Male circumcision and genital human papillomavirus: a systematic review and meta-analysis. Sex Transm Dis 2012;39:104-13.

38. Tobian AA, Serwadda D, Quinn TC, et al. Male circumcision for the prevention of HSV-2 and HPV infections and syphilis. N Engl J Med 2009;360:1298-309.

39. Turner AN, Morrison CS, Padian NS, et al. Male circumcision and women's risk of incident chlamydial, gonococcal, and trichomonal infections. Sex Transm Dis 2008;35:689-95.

40. Van Howe RS. Sexually transmitted infections and male circumcision: a systematic review and meta-analysis. ISRN Urol 2013;2013:109846.

41. El Bcheraoui C, Zhang X, Cooper CS, Rose CE, Kilmarx $\mathrm{PH}, \mathrm{Chen} \mathrm{RT}$. Rates of adverse events associated with male circumcision in U.S. medical settings, 2001 to 2010. JAMA Pediatr 2014;168:625-34.

42. Weiss HA, Larke N, Halperin D, Schenker I. Complications of circumcision in male neonates, infants and children: a systematic review. BMC Urol 2010;10:2.

43. Bocquet N, Chappuy H, Lortat-Jacob S, Chéron G. Bleeding complications after ritual circumcision: about six children. Eur J Pediatr 2010;169:359-62.

44. Cathcart P, Nuttall M, van der Meulen J, Emberton M, Kenny SE. Trends in paediatric circumcision and its complications in England between 1997 and 2003. Br J Surg 2006;93:885-90.

45. Wilcken A, Keil T, Dick B. Traditional male circumcision in eastern and southern Africa: a systematic review of prevalence and complications. Bull World Health Organ
2010;88:907-14.

46. Mihssin N, Moorthy K, Houghton PW. Retention of urine: an unusual complication of the Plastibell device. BJU Int 1999;84:745.

47. Özdemir E. Significantly increased complication risks with mass circumcisions. Br J Urol 1997;80:136-9.

48. Patel HI, Moriarty KP, Brisson PA, Feins NR. Genitourinary injuries in the newborn. J Pediatr Surg 2001;36:235-9.

49. Pieretti RV, Goldenstein AM, Pieretti-Vanmarcke R. Late complications of newborn circumcision: a common and avoidable problem. Pediatr Surg Int 2010;26:515-8.

50. Homer L, Buchanan KJ, Nasr B, Losty PD, Corbett HJ. Meatal stenosis in boys following circumcision for lichen sclerosus (balanitis xerotica obliterans). J Urol 2014;192:1784-8.

51. Ceylan K, Burhan K, Yilmaz Y, Can S, Kuş A, Mustafa G. Severe complications of circumcision: an analysis of 48 cases. J Pediatr Urol 2007;3:32-5.

52. Ince B, Gundeslioglu AO. A salvage operation for total penis amputation due to circumcision. Arch Plast Surg 2013;40:247-50.

53. Management of foreskin conditions. British Association of Paediatric Surgeons. Available from: http://www.baps. org.uk/resources/documents/management-foreskinconditions/. Accessed Jun 2015.

54. The Royal Australasian College of Physicians. Circumcision of infant males. 2010. Available from: https://www. racp.edu.au/docs/default-source/advocacy-library/ circumcision-of-infant-males.pdf. Accessed Jun 2015.

55. American Academy of Pediatrics Task Force on Circumcision. Circumcision policy statement. Pediatrics 2012;130:585-6.

56. American Academy of Pediatrics Task Force on Circumcision. Male circumcision. Pediatrics 2012;130:e756-85.

57. Crawford BS. Buried penis. Br J Plast Surg 1977;30:96-9.

58. Maizels M, Zaontz M, Donovan J, Bushnick PN, Firlit CF. Surgical correction of the buried penis: description of a classification system and a technique to correct the disorder. J Urol 1986;136:268-71.

59. O’Brien A, Shapiro AM, Frank JD. Phimosis or congenital megaprepuce? Br J Urol 1994;73:719-20.

60. Mattsson B, Vollmer C, Schwab C, et al. Complications of a buried penis in an extremely obese patient. Andrologia 2012;44 Suppl 1:826-8.

61. King IC, Tahir A, Ramanathan C, Siddiqui H. Buried penis: evaluation of outcomes in children and adults, modification of a unified treatment algorithm, and review of the literature. ISRN Urol 2013;2013:109349.

62. Donatucci CF, Ritter EF. Management of the buried penis in adults. J Urol 1998;159:420-4.

63. Chin TW, Tsai HL, Liu CS. Modified prepuce unfurling for buried penis: a report of 12 years of experience. Asian J Surg 2015;38:74-8.

64. Liu X, He DW, Hua Y, Zhang DY, Wei GH. Congenital completely buried penis in boys: anatomical basis and surgical technique. BJU Int 2013;112:271-5.

65. Chu CC, Chen YH, Diau GY, Loh IW, Chen KC. Preputial flaps to correct buried penis. Pediatr Surg Int 2007;23:111921.

66. Hughes DB, Perez E, Garcia RM, Aragón OR, Erdmann D. Sexual and overall quality of life improvements after surgical correction of "buried penis". Ann Plast Surg 2016;76:532-5. 